\title{
Natural Science Higher Order Thinking Skills Analysis of Junior High School Students
}

\author{
Rahmawati Darussyamsu ${ }^{1 *}$ Satri Vani Karisfa ${ }^{1}$ Fitri Arsih ${ }^{1}$ Fatma Rahmadhani ${ }^{1}$
}

\author{
${ }^{1}$ Biology Department, Math and Natural Science Faculty, Universitas Negeri Padang, Padang, Indonesia \\ *Corresponding author.rahmawati6786@gmail.com
}

\begin{abstract}
The 2013 curriculum is learning curriculum that emphasizes higher-order thinking skills, besides learning activities also by training students with questions based on high-level thinking skills, namely by Trends in International Mathematics and Sciences Study (TIMSS). The application of high-level thinking skills needs attention and assessment in its application to the learning process in schools, especially in science learning. This research is descriptive research. This research was conducted at SMPN 2 Padang, SMPN 7 Padang and, SMPN 8 Padang. The total sample of 120 students, with each school 40 students. The instrument used to collect data was the 2011 TIMSS question script. Analysis of the data used was by scoring and determining grades in each school. The results showed that the achievement of high-level thinking ability of superior state junior high schools was based on an average of low categorized value of 346.6. In the cognitive domain the average value obtained is 406.09 , the cognitive domain of application is 323.07 and the cognitive domain of reasoning is 286.68 . So based on the data obtained it can be concluded that the ability to think of high-level state junior high school students in the city of Padang is low.
\end{abstract}

Keywords: HOTS, Junior High School, Analysis

\section{INTRODUCTION}

The 2013 curriculum is a further step in the development of the Competency-Based Curriculum (CBC) which was initiated in 2004 and the Education Unit Level Curriculum (KTSP) 2006 which includes attitudes, knowledge and skills in an integrated manner. Curriculum development needs to be done because of the various challenges faced, both internal challenges and external challenges (Ministry of Education and Culture, 2014: 4). External challenges faced by the education world according to the Ministry of Education and Culture (2014: 4), among others, are related to future challenges, competencies needed in the future, community perceptions, the ability to think clearly and critically the development of knowledge and pedagogic, as well as various negative phenomena that emerge. The habit of thinking that results in an improved mindset is also highly recommended in the 2013 Curriculum.

The Government implemented the 2013 Curriculum to face the demands of education in the era of globalization. The theme for developing the 2013 curriculum is a curriculum that can produce Indonesian people who are productive, creative, innovative, affective through strengthening integrated attitudes, skills and knowledge (Kemendikbud, 2014: 24). Learning patterns The 2013 curriculum emphasizes higher-order thinking skills. Students' higher-order thinking skills can develop learning techniques that encourage students to explore their knowledge actively and independently.
Higher-level thinking referred to as a combination of critical thinking, creative thinking, and basic knowledge thinking. Thomas, Thorne \& Small in Aprianti (2013: 1) state that

higher-level thinking places thinking activities at a higher level than merely stating facts. In higher-order thinking, the concern is what will do with the facts. We must understand facts, relate facts to other facts, categorize, manipulate, use them together in new situations and apply them in seeking new solutions to new problems.

The importance of mastering high-level thinking skills listed in several points of High School Graduates Competency Standards, as in Permendiknas No. 23 of 2006 the expected points are: (1) students can build information or knowledge logically, critically, creatively, and innovatively, (2) show the ability to think logically, critically, creatively, and innovatively in decision making, and (3) demonstrate the ability to analyze and solve complex problems. High-level thinking in Bloom's Taxonomy is in the process of analysis (C4), evaluation (C5), and creation (C6). Cognitive processes of analyzing and evaluating are classified as critical thinking, while creating is classified as creative thinking (Ibrahim, 2015: 3). Students having high-level thinking skills not only memorize information but can apply information to new situations. Higher-order thinking skills also include students' reasoning skills (Rofiah et al., 2013: 17).

Efforts to improve students' scientific and higher-order thinking skills aside from learning activities must provide space for the development of cognitive domains and higher-order thinking skills, the questions used must also encourage and be able to measure cognitive domains and 
higher-order thinking skills such as Trends in International questions Mathematics and Sciences Study (TIMSS) (Barmoyo and Wasis, 2014: 9- 10). TIMSS is an International competency event to measure students' abilities in various fields of science including science and mathematics. The questions tested at TIMSS are divided into four categories, namely low measuring ability to the level of knowledge, intermediate measuring ability to level applying, high measuring ability to level reasoning and advanced measuring ability to level reasoning with incomplete information (Kemendikbud, 2014: 5).

The results of Indonesian students' competence at TIMMS in 2007 and 2011 in the field of Natural Sciences for Class VIII SMP students showed results that were far from satisfying. In the field of Natural Sciences, 2007 and 2011 showed that more than $95 \%$ of Indonesian students were only able to reach the intermediate level (Kemendikbud, 2014: 5). Researchers in the city of Padang also find that fact. Researchers conducted interviews in three schools that have accredited A in the city of three science teachers at 3 Padang Superior Schools in the city, namely Mrs. Defi Mailita S.Pd, a teacher at SMPN 7 Padang on January 10, 2017, Mrs. Murniati S.Pd, a teacher at SMPN 1 Padang on January 12, 2017, and Mrs. Hasyuni Hastuti S.Pd, a teacher at SMPN 12 Padang on January 17, 2017, two out of three teachers stated that the teacher had given a question on the level of analysis, but students were not yet able to answer. Because of this experience, the teacher no longer gave analysis questions in grades VII and VIII, only in class IX. However, the realities encountered by the teacher, students are still not able to answer.

This according to the teacher occurs because students accustomed to working on questions with a high cognitive level (Full interview results attached in Appendix 1). Thus it is known that although the school has implemented the 2013 Curriculum learning, it appears that students still lack high- level thinking skills. The application of higher-order thinking skills needs attention and assessment in its application to the learning process in schools, especially in science learning. Therefore, researchers are interested in researching: " Analysis of High-LevelThinking Ability of Junior High School Students Grade VIII in Padang City on IPA Material".

\section{METHODS}

\subsection{Type of Research}

This type of research is a descriptive study with a quantitative approach. Descriptive research with a quantitative approach according to Yusuf (2013: 61) one type of research that aims to describe systematically, factually and accurately about the facts and describe the phenomenon in detail.

\subsection{Research Place and Time}

The study was conducted in the second semester of 2016/2017 Academic Year. In January-May 2017. The place of the study conducted at the Superior Junior High School in Padang City, namely SMPN 2 Padang, SMPN 7 Padang, and SMPN 8 Padang.

\subsection{Population and Samples}

The population of this research was all students of class VIII of SMPN 2, SMPN7 and SMPN 8 Padang.

Table 1 Class Distribution in Each School of Research Sample of SMPN 2 SMPN 7 SMPN 8

\begin{tabular}{llllll}
\hline \multicolumn{2}{c}{ SMPN 2 } & \multicolumn{2}{c}{ SMPN 7 } & \multicolumn{2}{c}{ SMPN 8 } \\
\hline Class & $\begin{array}{c}\text { Total } \\
\text { Students }\end{array}$ & Class & $\begin{array}{c}\text { Total } \\
\text { Students }\end{array}$ & Class & $\begin{array}{c}\text { Total } \\
\text { Students }\end{array}$ \\
\hline VIII.1 & 30 & VIII.1 & 30 & VIII.A & 26 \\
\hline VIII.2 & 30 & VIII.2 & 30 & VIII.B & 26 \\
\hline VIII.3 & 30 & VIII.3 & 30 & VIII.C & 26 \\
\hline VIII.4 & 30 & VIII.4 & 30 & VIII.D & 26 \\
\hline VIII.5 & 30 & VIII.5 & 30 & VIII.E & 26 \\
\hline VIII.6 & 30 & VIII.6 & 30 & VIII.F & 25 \\
\hline VIII.7 & 30 & VIII.7 & 30 & VIII.G & 25 \\
\hline
\end{tabular}

The sampling technique in this study is Simple Random Sampling. A sampling of sample members from the population is done randomly without regard to strata that exist in that population. The total number of VIII grade students from all three schools was 600. Samples were taken $20 \%$ of 600 namely 120 students, with a research sample of 40 people for each school.

\subsection{Research Data}

The data in this study are primary data, which are obtained directly from research subjects. 


\subsection{Data Collection Instruments}

This research data is in the form of students' understanding of grade VIII of SMPN 2 Padang, SMPN 7 Padang and SMPN 8 Padang in solving high-level thinking questions. The data obtained by giving high-level thinking questions that will be answered by students of class VIII. Questions that have answered will be examined and analyzed. The research instrument was in the form of high-level thinking questions, namely TIMSS 2011 questions consisting of 32 biological questions and 22 physics questions. In each biology and physics problem consists of 3 categories, namely knowing, applying, and reasoning. Details on the categories of each material described in Table 2.

Table 2 Category of Material

\begin{tabular}{llllll}
\hline $\begin{array}{l}\text { Content } \\
\text { Domain }\end{array}$ & $\begin{array}{l}\text { Cognitif } \\
\text { Domain }\end{array}$ & $\begin{array}{l}\text { Number } \\
\text { of } \\
\text { Question }\end{array}$ & Objectives Essay & $\begin{array}{l}\text { Essay } \\
\text { Description } \\
\text { Answer }\end{array}$ \\
\hline Biology & Knowing & 11 & 7 & 4 & 0 \\
& Aplying & 12 & 6 & 4 & 2 \\
& Reasoning & 9 & 3 & 5 & 1 \\
\hline Physics & Knowing & 6 & 5 & 1 & 0 \\
& Aplying & 10 & 5 & 3 & 2 \\
& Reasoning & 6 & 1 & 5 & 0 \\
\hline
\end{tabular}

\subsection{Data Analysis Techniques}

Analysis of answers to higher-order thinking skills

\subsubsection{Scoring}

Scoring done on all student answers on the TIMSS test questions. The system of scoring answers is 1 if it is true and 0 if it is wrong for objective questions and short description questions. Problem description of the correct answer given a score of 2, partially correct given a score of 1 , and all given a score of 0 . Objective questions amounted to 27 questions with a score of 27 , while a brief description of 24 questions with a score of 24 , and the description of the answers to 5 questions with a score of 10 .

\subsubsection{Determination of value}

Data of high-level thinking ability (knowledge, application and reasoning) obtained by researchers from tests that have given a score converted to scores, based on the following criteria.

$$
\text { Value }=\frac{(\text { Scor Obtained x 700 })+100}{\text { Maximum Score }}
$$

Source: TIMSS (2011)
After obtaining the next value, is converted into the categories shown in Table 3

Table 3 LIST OF CONVERSION OF VALUE ABILITY THINKING AND ABILITY TEST RESULTS

\begin{tabular}{ll}
\hline Value & Category \\
\hline $625-800$ & Advance \\
$550-624$ & High \\
$475-549$ & Intermediate \\
$100-474$ & Low \\
\hline
\end{tabular}

\section{RESULT AND DISCUSSION}

\subsection{Result}

Based on research conducted on superior junior high school students in the city of Padang, obtained data on the achievement of high-level thinking abilities of students from research respondents namely students of SMPN 2, 7 and 8 Padang. Data obtained from test results using TIMSS questions that have translated. The results showed that students' high-level thinking abilities were relatively low on the tests. The low achievement results can be seen from the test results, both the total score and the cognitive level of knowledge, application and reasoning.

\subsubsection{Students' High-Level Thinking Skills Achievement Based on Grades}

Calculation of the average value based on the total score aims to describe the achievement of students' high-level thinking ability from all aspects of assessment. The maximum score that students must achieve is 61. The average score based on the total score achieved seen in Table 4.

Table 4. ACHIEVED ABILITY TO THINK HIGH LEVEL BASED ON VALUE

\begin{tabular}{lllll}
\hline No & School & $\begin{array}{l}\text { Average } \\
\text { Score }\end{array}$ & $\begin{array}{l}\text { Average } \\
\text { Value }\end{array}$ & Category \\
\hline 1 & SMPN 2 & 17,15 & 296,8 & Low \\
\hline 2 & SMPN 7 & 16,5 & 290 & Low \\
\hline 3 & SMPN 8 & 31,6 & 453 & Low \\
\hline 4 & Average & 21,75 & 346,6 & Low \\
\hline
\end{tabular}

Table 4 shows that SMPN 8 students achieved the highest score in answering TIMSS questions from SMPN 7 and SMPN 2 SMPN 8 students had the highest grades but the ability to think of high levels was still categorized as low, the same as SMPN 2 and SMPN 7. The category of scores that were said to be very high is $625-800$, the category of value said to be high is 550-624, the category of value that is said to be medium is $475-549$ and the 
category of low value is $100-474$ but the three junior high grades are smaller than 474 then it is categorized as low.

\subsubsection{Achievements of High-Level Thinking Abilities Based on Cognitive Domains of Knowledge}

The cognitive level of knowledge includes facts, information, concepts, measured through the ability to remember, define, describe, describe, and explain a tool or procedure. Scores obtained by students on the cognitive aspects of knowledge seen in Table 5.

Table 5 HIGH-LEVEL THINKING ABILITY ACHIEVEMENT IN COGNITIVE DOMAIN OF KNOWLEDGE

\begin{tabular}{lllll}
\hline No & School & $\begin{array}{l}\text { Average } \\
\text { Score }\end{array}$ & $\begin{array}{l}\text { Average } \\
\text { Value }\end{array}$ & Category \\
\hline 1 & SMPN 2 & 6,1 & 352,2 & Low \\
2 & SMPN 7 & 6,18 & 354,3 & Low \\
3 & SMPN 8 & 10 & 511,78 & Low \\
\hline 4 & Average & 15,6 & 406,09 & Low \\
\hline
\end{tabular}

From the data in Table 5 it can be seen that the scores of students of SMPN 2, 7, are still categorized low in the cognitive domain of knowledge because the value of each school is smaller than 474 . While the value of SMPN 8 included in the medium category of 511.78 . The category of value that is said to be very high is $625-800$, the category of value that is said to be high is 550-624, the category of value that is said to be medium is $475-549$ and the category of low value is $100-474$.

\subsubsection{Achievements of High-Level Thinking Ability in the Cognitive Domain of Application}

The cognitive level of the application shows the ability of students to focus on the ability of students to apply knowledge and understanding concepts to solve problems or answer questions. Scores obtained by students on the cognitive aspects of the application seen in Table 6.

Table 6. HIGH-LEVEL THINKING CAPABILITIES IN COGNITIVE DOMAIN APPLICATION

\begin{tabular}{lllll}
\hline No & School & $\begin{array}{l}\text { Average } \\
\text { Score }\end{array}$ & $\begin{array}{l}\text { Average } \\
\text { Value }\end{array}$ & Category \\
\hline 1 & SMPN 2 & 7,7 & 186,54 & Low \\
\hline 2 & SMPN 7 & 7,07 & 290,48 & Low \\
\hline 3 & SMPN 8 & 14,58 & 492,4 & Medium \\
\hline 4 & Average & 9,78 & 323,07 & Low \\
\hline
\end{tabular}

From the data in Table 6, the score of SMPN 2, 7 students in answering cognitive domain questions is still categorized as low because each school's score is smaller than 474. Meanwhile, SMPN categorized as moderate with a score of 492.4. The category of value that is said to be very high is $625-800$, the category of value that is said to be high is $550-624$, the category of value that is said to be medium is $475-549$ and the category of low value is 100 474.

\subsubsection{Achievements of High-Level Thinking Ability in the Cognitive Domain of Reasoning}

The The cognitive level of reasoning shows the ability of students to focus on solving non-routine problems, complex contexts and taking steps to solve many problems. Measured by the ability to compare, classify, use models, connect, interpret information, explain and find a solution to a problem. Scores obtained by students on cognitive aspects of reasoning seen in Table 7.

\section{Table 7 HIGH-LEVEL THINKING ABILITY ACHIEVEMENTS IN COGNITIVE DOMAINS IN REASONING}

\begin{tabular}{lllll}
\hline No & School & $\begin{array}{l}\text { Average } \\
\text { Score }\end{array}$ & $\begin{array}{l}\text { Average } \\
\text { Value }\end{array}$ & Category \\
\hline 1 & SMPN 2 & 3,325 & 229,3 & Low \\
2 & SMPN 7 & 3,275 & 227,4 & Low \\
3 & SMPN 8 & 7,8 & 403,33 & Low \\
\hline 4 & Average & 9,2 & 286,68 & Low \\
\hline
\end{tabular}

From the data in Table 7 it can be seen that the scores of students of SMPN 2, 7, and 8 categorized as low in answering cognitive domain questions of reasoning because the value of each school is smaller than 474 . The score and value of SMPN 8 students are higher than the other two junior high schools. The value of thinking ability level in the cognitive domain of reasoning is still relatively low.

\subsection{Discussion}

\subsubsection{Achievements of High-Level Thinking Ability Based on Value}

The results of high-level thinking skills of students in all schools in answering TIMSS questions earned scores and grades in the low category. The maximum score that should have been obtained by a superior state junior high school student in Padang was 61. However, the results of the high- level thinking ability test by using the TIMSS test score obtained by SMPN 2 students were with the highest score of 31 and the lowest score of 7, SMPN 7 getting the highest score 32 with the lowest score of 8 and at SMPN 8 got the highest score of 45 and the lowest score of 13 . 
The low level of thinking ability of students is due to several factors. Judging from the learning process as according to Bachman (2013) states that the entire learning process must be extended towards creative, critical and innovative thinking and these activities should be included in the learning process as part of all the acquisition of knowledge and its use framework. This explains, that the teaching and learning process is very important in gaining knowledge that leads to creative, critical and innovative thinking. According to Wardoyo (2013) also believes that the most important key in achieving learning objectives lies in the learning process that takes place in the classroom (Rofiah, 2013). It is very clear that the teacher has an important role, this is related to the teaching skills of a teacher in the use of media, classroom management, and variations in activities.

Low ability to think at a higher level can also be caused by learning that does not emphasize understanding and analysis (Herman, 2007). Rosnawati (2009) argues that higher-order thinking skills are skills that trained. This indicates that by often being trained and mentored, students' higher-order thinking skills can increase. The teacher also plays an important role again in this matter. Higher-order thinking skills that emphasize the realm of knowledge analysis, evaluating, and creating, make teachers have to go the extra mile to instill how to practice critical thinking skills, creative thinking, and problemsolving, which are the three aspects are indicators of higher-order thinking skills (Lewy, 2011). To practice these abilities certainly require the ability of teachers to create varied activities.

\subsubsection{High-Level Thinking Skills Achievement Based on Cognitive Knowledge Level}

Based on the results of research and analysis of the highlevel thinking ability of students at the cognitive level of knowledge of the two schools is still categorized as low, from the results of data analysis, the highest average score obtained by students of SMPN 8 Padang. Achievements of students in class VIII of SMPN 8 Padang have shown good results but are categorized as a medium, while students of SMPN 2 and SMPN 7 Padang have achievements below SMPN 8 Padang with a low category. Based on the scores obtained by each superior SMPN it can be seen that SMPN 8 gets the highest score 13 out of 17 maximum scores and the lowest score 4, in SMPN 2 gets the highest score 12 and the lowest score 2, and on SMPN 7 gets the highest score 11 and the lowest score 2 This result occurs because according to students the questions given on the higher-level thinking ability test are more difficult than the usual exam questions given by the teacher.

The cognitive level of knowledge based on the data in Table 5 the average highest score of students is at the cognitive level of knowledge while the lowest average value is at the cognitive level of reasoning. According to Anggraini (2014: 17) said that the characteristics of
TIMSS questions tended to test comprehension skills. When viewed from the TIMSS results, Indonesia's ranking is still in the lower group and its score acquisition is still very low. So it can be said that the ability of Indonesian students to work on problems that demand the ability to understand conceptual knowledge is still low. This is in line with the opinion of Sanjaya (2008) that the learning process, especially physics, does not yet refer to students' thinking abilities and understanding of physics concepts. According to Anggraini (2014: 17) This conceptual understanding is important for students to have. Without conceptual knowledge, students will have difficulty in solving more complex problems. When students have gained conceptual understanding, they can provide arguments to explain why some facts are the result of other facts. Knowledge in this sense according to Gunawan and Anggraini (2013: 18) involves the process of recalling specific and universal things, recalling methods and processes, or recalling patterns, structures. Knowledge of the generality (universality) and abstraction in a field that is about the main schemes and patterns for organizing phenomena and ideas.

\subsubsection{Achievement of High-Level Thinking Ability Based on the level of Cognitive Application}

The ability of students at the cognitive level of application based on Table 6 the highest schools namely SMPN 8 followed by SMPN 2 and SMPN 7. At the cognitive level of this application, it can be seen from the achievement of the highest score at SMPN 8 is 22 out of 26 maximum scores while the lowest score is 5, SMPN 7 got the highest score of 15 with the lowest score of 2 and SMPN 2 got the highest score of 13 of the lowest score 3 . The average student was able to solve the application cognitive domain problems at TIMSS because implementation problems were routine problems where students often encountered these problems in learning at school so students can be easier to solve than the problem of reasoning. Application refers to cognitive processes utilizing or using a procedure to carry out experiments or solve problems. The application relates to the dimension of procedural knowledge, including the activities of carrying out procedures and implementing (Yuliati, 2013).

Implementation is a continuous process, starting from students solving a problem using standard procedures that are already known. This activity regularly runs so that students are truly able to carry out this procedure easily, then continue to the emergence of new problems that are foreign to students, so students are required to be familiar with the problem and choose the right procedure to solve the problem (Gunawan and Anggraini, 2013: 27). The problem with the application category so far is that learning done in schools through textbooks is that the dominant BSE trains questions at the application level. This should show that Indonesian students can work on TIMSS questions better because the questions trained also 
meet the same criteria as TIMSS questions, even UN questions have a higher level of reasoning than TIMSS questions (Barmoyo and Wasis, 2014: 12).

\subsubsection{Achievement of High-Level Thinking Ability Based on the level of Cognitive Reasoning}

The highest average value of superior SMPN in Padang at the cognitive level of reasoning is SMPN 8 and followed by SMPN 2 and SMPN 7. The cognitive level of reasoning is the lowest percentage in giving answers. The maximum score that should be obtained by students is 18 , SMPN 8 gets the highest score 14 with the lowest score 2, SMPN 7 gets the highest score 11 and the lowest score 0, SMPN 2 gets the highest score 8 with the lowest score 1 . This is due to the low reasoning ability of students. The ability of reasoning in students is low by showing that errors that occur in the matter of reasoning are in the high category. If the cognitive domain of TIMSS reasoning seen, students still have difficulty in solving problems, this can see from students' difficulties in solving problems and applying

\section{CONCLUSION}

Based on the results of research and analysis of high-level thinking ability tests of students of class VIII of superior SMP in Padang, it concluded that the achievement of highlevel thinking skills based on the average scores of the three schools still categorized as low.

\section{REFERENCES}

[1] Adi, W.G.,2003. Genius Learning Strategi. Jakarta: Gramedia Pustaka Utama. Anggraini, N.2014. Pengembangan Soal IPA-Fisika Model TIMSS (Trends In

[2] International Mathematics And Science Study). Jurnal InovasiPendidikan Fisika (JIPF), Vol.03 No.01. Hlm.15-18.

[3] Aprianti, V.2013. Pengaruh Penerapan Model Cooperative Learning Tipe Think Pair Share (TPS)terhadap Kemampuan Berpikir Kritis Siswa Pada Pembelajaran Ekonomi. Jurnal Pendidikan, Vol.01 No.01. Hlm. 1-9.

[4] Bachman, E.2013. Metode Belajar Berpikir Kritis dan Inovatif. Jakarta: Prestasi Pustaka.

[5] Barmoyo, Q.N., dan Wasis. 2014. Analisis soalsoal dalam BSE, UN, Dan TIMSSDitinjau dari Domain Kognitif dan Indikator Keteramilan Berpikir Kritis. Jurnal Inovasi Pendidikan Fisika (JIPF), Vol. 03 No 01. Hlm. 8-14.

[6] Crawford, L.B.2004. Factors Influencing The Problem Solving of College Students Solving A Mathematics Problem in A Small Group: Two Case Studies. A Dessertation Submitted to the Graduated Faculty of TheUniversity of Georgia facts, concepts and procedures (Istiyono, 2014). The reasoning is solving a problem by separating each part of the problem and looking for the linkages of each of these parts and finding out how these links can cause problems.

This ability is a type of ability that highly demanded from learning activities in schools and schools (Suryadi, 2005). Various subjects require students to have the ability to analyze well (Kurniati, 2016). The demands of students having the ability to analyze often tend to be more important than other dimensions of cognitive processes such as evaluating and creating (Gunawan and Anggraini, 2013: 28). Students' understanding in understanding the problem still has obstacles, this is because students not accustomed to working on TIMSS- based science questions, so far students are only familiar with the questions given in books or worksheets and those given by the teacher (Putri, Ahda, and Darussyamsu, 2018) and also affected by teachers' learning strategy in class (Haryanto, Ahda, and Darussyamsu, 2018). One other factor is that it is difficult for students to answer these TIMSS questions because the TIMSS question form rarely encountered in learning or examinations held by schools or government.

\section{in Partial Fulfillment of The Requirements ForThe Degree.}

[7] Gunawan,I., Anggraini,R.P. 2013. Taksonomi Bloom Revisis Ranah Kognitif Kerangka Landasan untuk Pembelajaran, Pengajaran dan Penilaian. Prosiding Seminar Pendidikan FIP IKIP Madiun, Madiun 12 Juli 2013.

[8] Haryanto, H., Ahda, Y., \& Darussyamsu, R. 2018. Analisis Aspek Kemampuan Berpikir Tingkat Tinggi pada Instrumen Penilaian Materi Fungi untuk Peserta Didik SMA/MA Kelas X. Atrium Pendidikan Biologi, Vol. 3 No. 1, eISSN: 2656-1700.

[9] Herman, T. 2007. Pembelajaran Berbasis Masalah untuk Menigkatkan Kemamapuan Berpikir MatematisTingkat Tinggi Siswa Sekolah Menengah Pertama. Educationist, vol1(2), 1907-8838.

[10]Heong, T.M., Othman, W.D., Md Yunos, J., Kiong, T.T., Hassan, R., \& Mohammad, M.M. 2011. The Level of Marzano Higher Order Thinking Skills Among Technical Education Students, International Journal ofSocial and Humanity, Vol.1, No.2, July 2011, 121-125.

[11] Ibrahim, M. Berpikir Tingkat Tinggi (Higher Order Thinking). Prosiding seminarPendidikan FMIPA di Universitas Negeri Jakarta, Jakarta, 11 April 2015.

[12] Istiyono, 2014. Pengembangan Tes Kemampuan Berpikir Tingkat Tinggi Fisika Peserta Didik SMA. Jurnal Penelitian dan Evaluasi Pendidikan, 18(1), 1- 12.

[13] Kawuwung, F. 2011. Profil Guru, Pemahaman Kooperatif NHT, Dan Kemampuan Berpikir 
Tingkat Tinggi di SMP Kabupaten Minahasa Utara. Jurnal Elhayah, Vol 1, No.4.

[14] Kemendikbud. 2014. Materi Pelatihan Guru Implementasi Kurikulum 2013 tahunpelajaran 2013/2014. Jakarta: Kemendikbud.

[15] Kementerian Pendidikan dan Kebudayaan. 2014. Konsep dan ImplementasiKurikulum. Paparan Wakil Menteri Pendidikan dan Kebudayaan RI Bidang Pendidikan, Jakarta, 14 Januari 2014.

[16] King, J.F., Goodson, L., Rohani, F. 2010. Higher Order Thinking Skills,Definition, Teaching Strategis, Assesment. A Publication of The Educational Service Program. Tersedia di www.Cala.fsu.edu Diakses 2 Januari 2017.

[17] Kurniati, D. 2016. Kemampuan Berpikir Tingkat Tinggi Siswa SMP di Kabupaten Jember dalam Menyelesaikan Soal Berstandar PISA. Jurnal Penelitian dan Evaluasi Pendidikan, 20(2), 142155.

[18]Lewis, A \& Smith, D. 1993. Defining Higher Order Thinking. Theory Into Practice, 32 (3).

[19]Lewy, L. 2011. Pengembangan Soaluntuk Mengukur Kemampuan Berpikir Tingkat Tinggi Pokok Bahasan Barisan Dan Deret Bilangan Di Kelas IX Akselerasi SMP Xaverius Maria Palembang. Jurnal Pendidikan Matematika, 5(1).

[20] Mahanal, R.J. 2005. Strategi Pembelajaran Biologi, Jenis Kelamin, dan Pengaruhnya terhadap Kemampuan Berpikir Kritis. Prosiding SeminarNasional IX Pendidikan Biologi FKIP UNS.

[21]Mulyasa, E. 2013. Pengembangan dan Implementasi Kurikulum 2013.

[22] Bandung: Remaja Rosdakarya.

[23] Olyvia, S. 2015. Analisis Kemampuan Berpikir Tingkat Tinggi Siswa Kelas XISMA Negeri Kota Padang dalam Pembelajaran Biologi. Tesis dipublikasikan. Padang: Universitas Negeri Padang.

[24]Permendiknas No. 23 Tahun 2006. Standar Kompetensi Lulusan untuk SatuanPendidikan Dasar dan Menengah. Jakarta: Depdiknas.

[25]Poedijadi, A.2005. Sains Teknologi dan Masyarakat. Bandung: Remaja Rosdakarya.

[26] Putri, R.R., Ahda, Y., \& Darussyamsu, R. 2018. Analisis Aspek Kemampuan Berpikir Tingkat Tinggi pada Instrumen Penilaian Materi Protista untuk Peserta Didik SMA/MA Kelas X. Jurnal Biodik, Vol. 4 No. 1, Juni, e- ISSN: 2580-0922.

[27]Rofiah, E., Nonoh S.A., \& Elvin Y.K. 2013. Penyusunan Instrumen Tes Kemampuan Berpikir Tingkat Tinggi Fisika pada Siswa SMP.JurnalPendidikan Fisika, Vol. 1, No. 2 ISSN: 2338-0691.

[28] Rosnawati.2009. Enam Tahapan Aktivitas Dalam Pembelajaran MatematikaUntuk Mendayagunakan Berpikir Tingkat Tinggi Siswa (disampaikan dalam seminar nasional) Yogyakarta: UNY.

[29] Sastrawati,E., Muhamad R., \& Syamsurizal. 2011.Problem Based Learning, Strategi Metakognisi, dan Keterampilan Berpikir Tingkat tinggi Siswa. Jurnal Tekno-Pedagogi Vol. 1 No. 2, ISSN : 20080205X.

[30] Sanjaya,W.2008. Pembelajaran dalam Implementasi Kurikulum BerbasisKompetensi. Jakarta: Kencana Prenada Media Grup.

[31] Solihat, N.A. 2014. Studi Komparatif pengguna Metode Pembelajaran BerbasihMasalah (problem based learning)dan Metode PembelajaranPemecahan Masalah (Problem Solving)dalam MeningkatkanKemampuan berpikir kreatif siswa Universitas Pendidikan Indonesia. Bandung: Universitas Pendidikan Indonesia.

[32] Sukmadinata, N.S.2010.Metode Penelitian Pendidikan. Bandung: RosdaKarya. Suryadi, D. 2005. Penggunaan Pendekatan Pembelajaran Tidak Langsung

[33]Dalam Rangka Meningkatkan Kemampuan Berpikir Matematik Tingkat

[34] Tinggi Siswa SLTP. Diss Universitas Indonesia

[35] Suryani, E. 2015. Analisis Kemampuan Siswa dalam Menyelesaikan Soal- soalTIMSS di SMP Kota PadangSidimpuan. Tesis dipublikasikan. Padang: Universitas Negeri Padang.

[36] Susilo, A.B.2012. Pengembangan Model Pembelajaran IPA Berbasis Masalah Untuk Meningkatkan Motivasi Belajar Dan Berpikir Kritis Siswa SMP. Jurnal Pendidikan, Vol 1, No. 1, ISSN: 2252-6404. TIMSS. 2011. Perfomance at the TIMSS 2011 International Benchmarks. http://timssandpirls.bc.edu/. Diakses 23 Januari 2017.

[37] Wahyuni, R. 2014. Analisis Kesesuaian Materi Dalam Buku Guru Dan SiswaBerdasarkan Kurikulum 2013 Pada Mata Pelajaran IPA Di SMP SertaImplementasinya Dalam Proses Pembelajaran. Bandung: Universitas Pendidikan Indonesia.

[38] Wardoyo, M.S. 2013. Pembelajaran Kontruktivisme Teori dan AplikasiPembelajaran dalam Pembentukan Karakter. Bandung: Alfabeta.

[39] Ramadhan, D., Wasis. 2013. Analisis Perbandingan Level Kognitif Dan Keterampilan Proses Sains Dalam Standar Isi (SI), Soal Ujian Nasional (UN), Soal (Trends In International Mathematics And Science Study (TIMSS), dan Soal Programme For International Student Assesment (PISA). Jurnal Inovasi Pendidikan Fisika, Vol 02, No 01,20-25.

[40] Widhy, P. Langkah Pengembangan Pembelajaran 
IPA pada Implementasi Kurikulum 2013. Prosiding Diklat Penyusunan Worksheets IntegretedScience Process Skills Bagi Guru IPA SMP kabupaten Sleman Menyongsong Implementasi Kurikulum 2013, 24 dan 31 Agustus 2013.

[41] Widyastono, H. 2014. Pengembangan Kurikulum di Era Otonomi Daerahdari kurikulum 2004, 2006, ke Kurikulum 2013. Jakarta: Bumi Aksara.

[42] Yuliati, 2013. Efektivitas Bahan Ajar IPA Terpadu Terhadap Kemampuan Berpikir Tingkat Tinggi Siswa SMP.Jurnal Pendidikan Fisika Indonesia, 9(1).

[43] Yusuf, M. 2013. Metode Penelitian Kuantitatif, Kualitatif \& PenelitianGabungan. Jakarta: PT. Fajar Interpratama. 